\title{
Medicine, connoisseurship, and the animal body
}

\author{
Alexander Wragge-Morley
}

In 1719, an anonymous pamphlet announced that the physician, collector, and natural philosopher John Woodward had died. Allegedly written by the encyclopaedist John Harris (1666-1719), one of his friends, the pamphlet detailed Woodward's agonising final days. In addition, it described the post-mortem dissection carried out on his body. ${ }^{1}$ The autopsy showed that Woodward had been killed by a vast accumulation of bile arising from his stomach and guts. It also revealed that those bilious salts had transformed the doctor's internal organs. ${ }^{2}$ His liver, of prodigious size and "divided into seven lobes," was much like that of an ox. His triangular spleen, by contrast, resembled that of an ape. His unusually positioned testicles, too, more closely resembled those of an ape than a man. Rather than hanging loosely, they were tucked up tightly into the groin. Woodward's brain appeared to have suffered as well. The bilious salts arising from the stomach and guts had wholly "obliterated" the twists and turns of his cerebral cortex, giving it the "plain and even" surface sometimes identifiable in people of limited mental capacity. The pineal gland, identified by the philosopher René Descartes (15961650) as the immaterial soul's place of residence in the body had been similarly deformed. Rendered "perfectly flaccid," that organ "seem'd to have been incapable for some Time of

Acknowledgments: For their help in writing this essay, I am very grateful to acknowledge Cécile Bishop and Michael Bycroft. I am also very grateful to Courtney Weiss Smith for giving me the opportunity to present this project at the Wesleyan University College of the Environment Think Tank, and to all the members of the Think Tank for their generous comments. I would also like to thank Matthew Stanley for inviting me to present this project at the NYC history of science workshop, and to those who attended for their valuable suggestions. Finally, I would like to thank Lissa Roberts, the editor of History of Science, and the two anonymous reviewers for their very useful criticisms and suggestions.

${ }^{1}$ Dr. Technicum [pseud.], An Account of the Sickness and Death of Dr. W---DW---ARD; As Also, of what appear'd upon opening his BODY (London, 1719). The pseudonym 'Dr. Technicum' refers to John Harris's Lexicon Technicum: or, an Universal Dictionary of the Arts and Sciences, 2 vols. (London, 1708-1710), thus falsely insinuating Harris's authorship.

${ }^{2}$ Sickness and Death, p. 9 (note 1). 
giving any proper Directions to the Will." Before killing him, Woodward's sickness had turned him into an animal, no longer capable of using the immaterial part of his mind - the rational soul - to control his body. ${ }^{3}$

In truth, Woodward (1665 or 1668-1728) was still alive, remaining that way for almost another decade. It is difficult to tell exactly who wrote An Account of the Sickness and Death of $D r . W---D W---A R D$. The pamphlet, however, was one of several exchanged in the course of a controversy among British medics that reached its peak in the first half of $1719 .{ }^{4}$ The affair began in 1718, when Woodward published The State of Physick: and of Diseases [...] But more particularly of the Small-Pox, a book on the causes of disease and the treatment of smallpox. There, he sharply criticised the physician John Freind (1675-1728), who had earlier advanced a cure for smallpox based on purgative medicines in a set of commentaries on the Epidemics of Hippocrates. Woodward charged not only that Freind's cure was mistaken, but that he had been led into that error by an excessive regard for the authority of ancient learning. The dispute thus reproduced a key theme in the cultural politics of the early $18^{\text {th }}$ century - the debate about the comparative worth of ancient and modern models of learning and self-cultivation. ${ }^{5}$

The differences between the participants in this debate were not as clear-cut as they might at first seem. Freind and his allies tended to portraye themselves as supporters of ancient learning, emphasising the textual expertise needed to grasp the medical and scientific

\footnotetext{
${ }^{3}$ Ibid., pp. 11-12.

${ }^{4}$ The participants in this pamphlet war published anonymously. Joseph M. Levine attributes the Sickness and Death to the physician and satirist John Arbuthnot (ca. 1667-1735), based on its inclusion in a later collection of Arbuthnot's works. See Joseph M. Levine, Dr Woodward's Shield: History, Science, and Satire in Augustan England (Berkeley: University of California Press, 1977), p. 15. L.M. Beattie, however, doubted this attribution. See L.M. Beattie, John Arbuthnot, Mathematician and Satirist (Cambridge, MA: Harvard University Press, 1935), pp. 242, 251-53.

${ }^{5}$ Levine, Dr. Woodward's Shield, pp. 9-10 (note 4); Sophie Vasset, "Medical Laughter and Medical Polemics: The Woodward-Mead Quarrel and Medical Satire," Revue de la Société d'études anglo-américaines des XVIIe et XVIIIe siècles 70 (2013), 109-133, 110. On Freind and Mead as followers of Newton, see Anita Guerrini, “Archibald Pitcairne and Newtonian Medicine,” Medical History 31:1 (1987), 70-83, 82 and Ludmilla Jordanova, "Portraits, People and things: Richard Mead and Medical Identity," History of Science 41:3 (2003), 293-313, 301-303. On Newtonianism and ancient learning, see Craig Ashley Hanson, The English Virtuoso: Art, Medicine, and Antiquarianism in the Age of Empiricism (Chicago: University of Chicago Press, 2009), p. 164.
} 
accomplishments of Greece and Rome. The physician and art collector Richard Mead (16731754), for instance, took every opportunity to advertise his intellectual debts to ancient physicians. At the same time, however, physicians like Mead and Freind identified themselves as practitioners of modern Newtonian science, using ostensibly empirical methods of inquiry, and basing their explanations for the causes and cures of disease on hypotheses that Newton had advanced. Meanwhile, Woodward and his allies claimed to reject ancient learning, brashly asserting that the empirical study of nature required its practitioners to be indifferent to the authority of authors such as Hippocrates and Galen. In the State of Physick, Woodward thus claimed that his empiricism had enabled him to identify the true cure for smallpox that his opponents had overlooked - a course of oleaginous medicines accompanied by judiciously administered vomits. ${ }^{6}$ As Joseph Levine has shown, Woodward nevertheless took a close interest in the legacies of antiquity, whether mobilising ancient texts and archaeological specimens to support his speculations about the age of the earth, or to defend his notoriously incorrect assertion that he had come into the possession of an authentic Roman shield. ${ }^{7}$

Given the scope of their interests, it is hardly surprising that the antagonism between Woodward and his opponents extended beyond strictly medical questions, encompassing matters of taste and discernment. As well as lampooning his ideas about medicine, Woodward's opponents mercilessly attacked him for his bad taste. More specifically, they held him up as a bad connoisseur, unable to form correct judgments about the aesthetic and monetary value of precious material things. In his day, Woodward was a famous collector, known for the valuable cabinet of fossils and geological specimens through which he pursued his ambitious programme of research into the history of the earth since its first formation. The author of the Sickness and Death, however, wrote off that famous collection as a mere "Knicknackatory," perhaps worth

\footnotetext{
${ }^{6}$ Levine, Dr. Woodward's Shield, pp. 11-13 (note 4).

${ }^{7}$ Levine, Dr. Woodward's Shield (note 4).
} 
just enough to pay off Woodward's funeral expenses and settle the final bill for emetics from his druggist. ${ }^{8}$ It is now well known that the medics of the early $18^{\text {th }}$ century used arguments about aesthetic judgment, taste, and connoisseurship, to pursue debates about the causes and cures of disease. As Craig Ashley Hanson, Ludmilla Jordanova, and Joseph Levine have shown, connoisseurship provided physicians with another means of positioning themselves in the medical version of the debate between the ancients and the moderns. Woodward thus signalled his esteem for the moderns by focusing on geology, while his opponents, especially Mead, advertised their preference for the ancients by acquiring paintings, prints, and works or representations of classical sculpture. Jordanova and Levine have both advanced sociological explanations for the way the medics of early $18^{\text {th }}$-century Britain - especially London - used connoisseurship, showing that figures such as Mead used the collection and display of precious material things both to enhance their social status as individuals, and that of their profession. ${ }^{9}$

There is no need, therefore, to repeat the now familiar observation that physicians like Mead and Woodward took a close interest in the connoisseurship of art and literature. Instead, this essay seeks to explain why the participants in the debate between Freind and Woodward including Freind's ally Mead - so persistently identified questions about the causes and cures of disease with those at stake in forming judgments about the aesthetic, epistemic, or pecuniary value of art objects and curiosities. My aim, in other words, is to uncover the ideas and practices that made it possible for medics such as Mead and Woodward to so seamlessly mobilise aesthetics and connoisseurship in a disagreement about how to explain and treat smallpox. It is worth remarking at the outset, moreover, that the pamphlet war between Mead and Woodward sheds light on broader issues concerning the interrelationships between the arts and sciences in

\footnotetext{
${ }^{8}$ Sickness and Death, p. 8 (note 1). John Arbuthnot parodied Woodward and his collection in The Memoirs of Martinus Scriblerus. See Levine, Dr. Woodward's Shield, pp. 245-46 (note 4).

${ }^{9}$ In addition to the works by Levine and Jordanova already cited, see Hanson, English Virtuoso, pp. 171-183 (note 5).
} 
early modern Europe. As Craig Ashley Hanson demonstrates in his book The English Virtuoso (2009), medics such as Mead had a central role in the emergence and institutionalization of the art market in $18^{\text {th }}$-century London. ${ }^{10}$ Through an analysis of the intellectual strategies used by Freind's allies to attack Woodward, this essay aims to explain precisely why the medics of the early $18^{\text {th }}$ century believed themselves capable of making authoritative pronouncements on matters of taste and aesthetic judgment - and perhaps why some of their contemporaries acquiesced in those pronouncements. In so doing, I will uncover an obvious but hitherto overlooked point of connection between European medicine and connoisseurship of the early $18^{\text {th }}$ century: their mutual dependence on the bodily organs involved with the perception, consumption, and even digestion of material things.

In recent years, historians have sought to revise the surprisingly tenacious view that the defining feature of $18^{\text {th }}$-century European thought was its concern with reason, all but ignoring the coarser bodily processes at stake in processes such as the consumption of food, and its digestion. Scholars such as Rebecca Anne Barr, Anne C. Vila, Sylvie Kleinman-Lafon, Aris Sarafianos, and Sophie Vasset have shown instead that many of those thinkers preoccupied themselves just as much with the organs of the lower body - organs such as the intestines, liver, spleen, and stomach. Far from regarding the mind as the product of reason alone, philosophers and medics frequently explored the possibility that the affective and cognitive operations of the mind could be decisively influenced by less obviously intellectual processes such as the digestion of food, or the filtration of nutriment from the guts into the blood. ${ }^{11}$ In this essay, I will use such a focus on the role of the lower body in mental processes to reconsider the links

\footnotetext{
${ }^{10}$ Hanson, English Virtuoso, pp. 157-193 (note 5).

${ }^{11}$ See Rebecca Anne Barr, Sylvie Kleiman-Lafon and Sophie Vasset, "Introduction: Entrails and Digestion in the Eighteenth Century," in their edited volume Bellies, Bowels and Entrails in the Eighteenth Century (Manchester: Manchester University Press, 2018), 1-23. For French thought in the $18^{\text {th }}$ century, see Anne C. Vila, Enlightenment and Pathology: Sensibility in the Literature and Culture of Eighteenth-Century France (Baltimore: Johns Hopkins University Press, 1998). Aris Sarafianos has shown that Edmund Burke (1729-1797) emphasized the role of the lower body in aesthetic experience. See "Pain, Labor, and the Sublime: Medical Gymnastics and Burke's Aesthetics," Representations 91:1 (2005), 58-83.
} 
between British medicine, connoisseurship, and aesthetic theory in the early $18^{\text {th }}$ century. Taking the satire on Woodward's body as its starting point, we will see that what medicine and connoisseurship had in common was a preoccupation with the body's influence over the mind. Both Woodward and his opponents believed that judging the causes of disease and assessing the value of material things depended on similarly delicate intellectual operations. They feared, however, that those operations could easily be disrupted by disorders arising from the organs of the lower body.

Pursuing this line of argument will therefore make it possible to do more than explain the debates and questions that motivated the participants in the conflict between Woodward and his enemies. At the same time, this essay will reconsider the place of mind-body dualism in the medicine and aesthetics of early $18^{\text {th }}$-century Britain. With the exception of materialists such as the philosopher-physician Bernard Mandeville (1670-1733), medics and aesthetic theorists tended to identify the exercise of judgment with the operations of a disembodied mind, unsullied by the embodied mechanisms of the lower body. In practice, however, the insistence that the most refined forms of judgment depended on the presence and activity of a disembodied, immaterial soul was less meaningful than it seems. ${ }^{12}$ Even medics and connoisseurs who claimed to believe in the existence and activity of the immaterial soul were intensely preoccupied by the possibility that the mind might be controlled by the material processes going on in the lower body. When confronted by failures of judgment, whether in medicine or connoisseurship, they frequently insisted on the power of the animal body over the supposedly disembodied operations of the mind, putting forward strikingly materialist explanations for failures of medical judgment and connoisseurship alike. Whether or not they

\footnotetext{
${ }^{12}$ Harold J. Cook, "Bernard Mandeville and the Therapy of the "Clever Politician,"”' Journal of the History of Ideas 60:1 (1999), 101-124, especially 122-23. See also Charles T. Wolfe, "Tres medici, duo athei? The Physician as Atheist and the Medicalization of the Soul," in Peter Distelzweig, Benjamin Goldberg, and Evan R. Ragland (eds.), Early Modern Medicine and Natural Philosophy, History, Philosophy and Theory of the Life Sciences 14 (Dordrecht: Springer, 2016), 343-366.
} 
believed in the immateriality of the soul, they often pictured the mind as a malfunctioning animal machine, to be cured through the material agency of medical therapeutics.

\section{Connoisseurs, mountebanks, and monkeys}

During the $17^{\text {th }}$ and $18^{\text {th }}$ centuries, one animal appeared frequently in European depictions of both bad connoisseurship and false medical expertise - the monkey or ape. The image of a monkey scrutinizing a painting with a magnifying glass was a commonplace in depictions of poor taste in art. As Harry Mount has pointed out, practising artists frequently used that image to attack non-practising connoisseurs for valuing the surface finish of a painting more than its overall composition. Such a monkey can be found inspecting a maritime scene in a detail from Jan Brueghel the Elder and Peter Paul Rubens's allegorical depiction of The Sense of Sight (1617). 


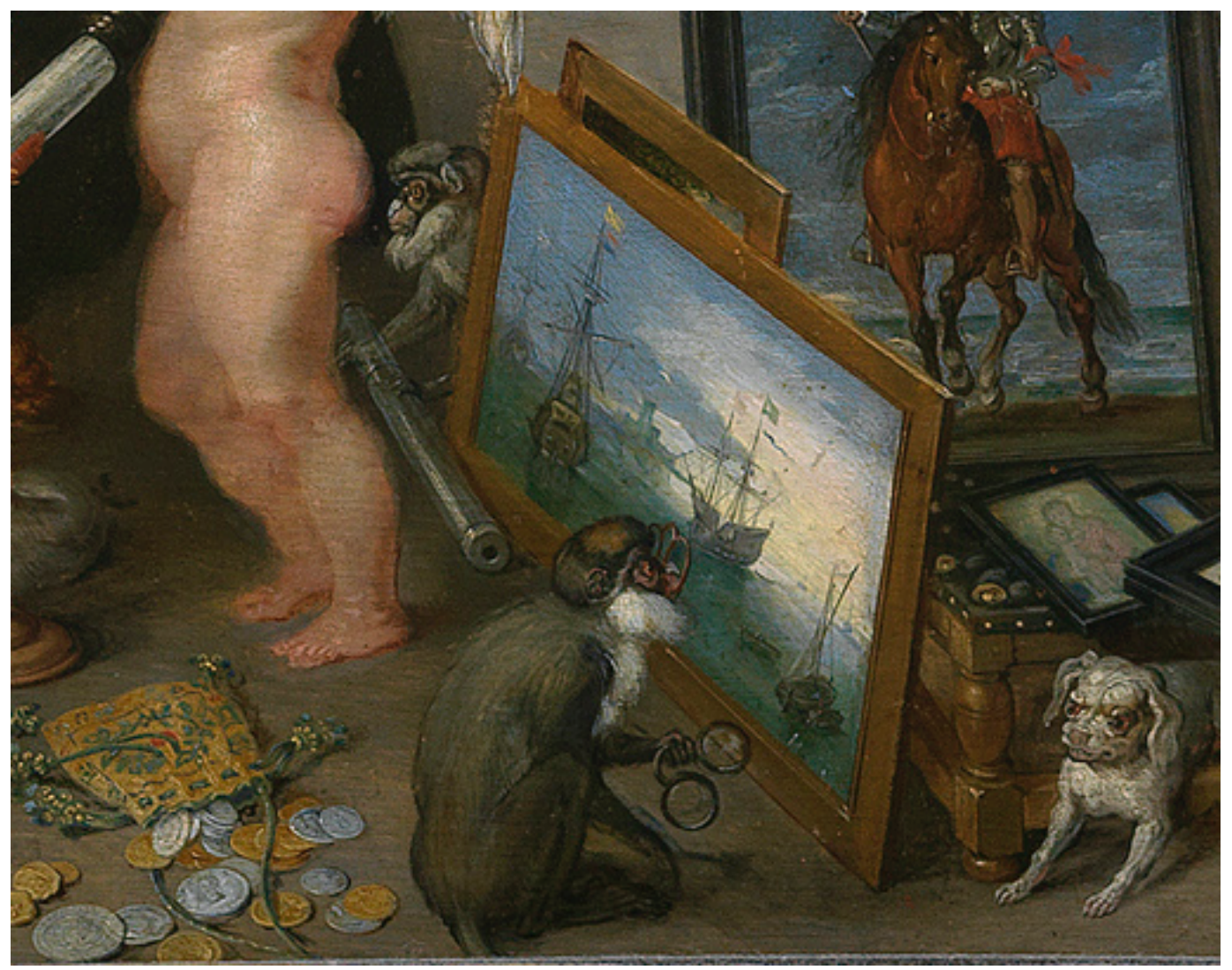

Figure 1: Detail from The Sense of Sight (1617) by Peter Paul Rubens and Jan Brueghel the Elder. (C) Museo Nacional del Prado. Note the second monkey, holding a telescope while staring at the cherub's buttocks.

Another such monkey appeared 150 years later in a print drawn by William Hogarth (16971764). There, Hogarth used a fashionably dressed simian inspecting desiccated old plants with a magnifying glass to satirize the excessive regard in which British armchair connoisseurs held foreign old master paintings. ${ }^{13}$

\footnotetext{
${ }^{13}$ Harry Mount, "The Monkey with the Magnifying Glass: Constructions of the Connoisseur in EighteenthCentury Britain," Oxford Art Journal 29:2 (2006), 169-184. On Hogarth’s print, see 171-72.
} 


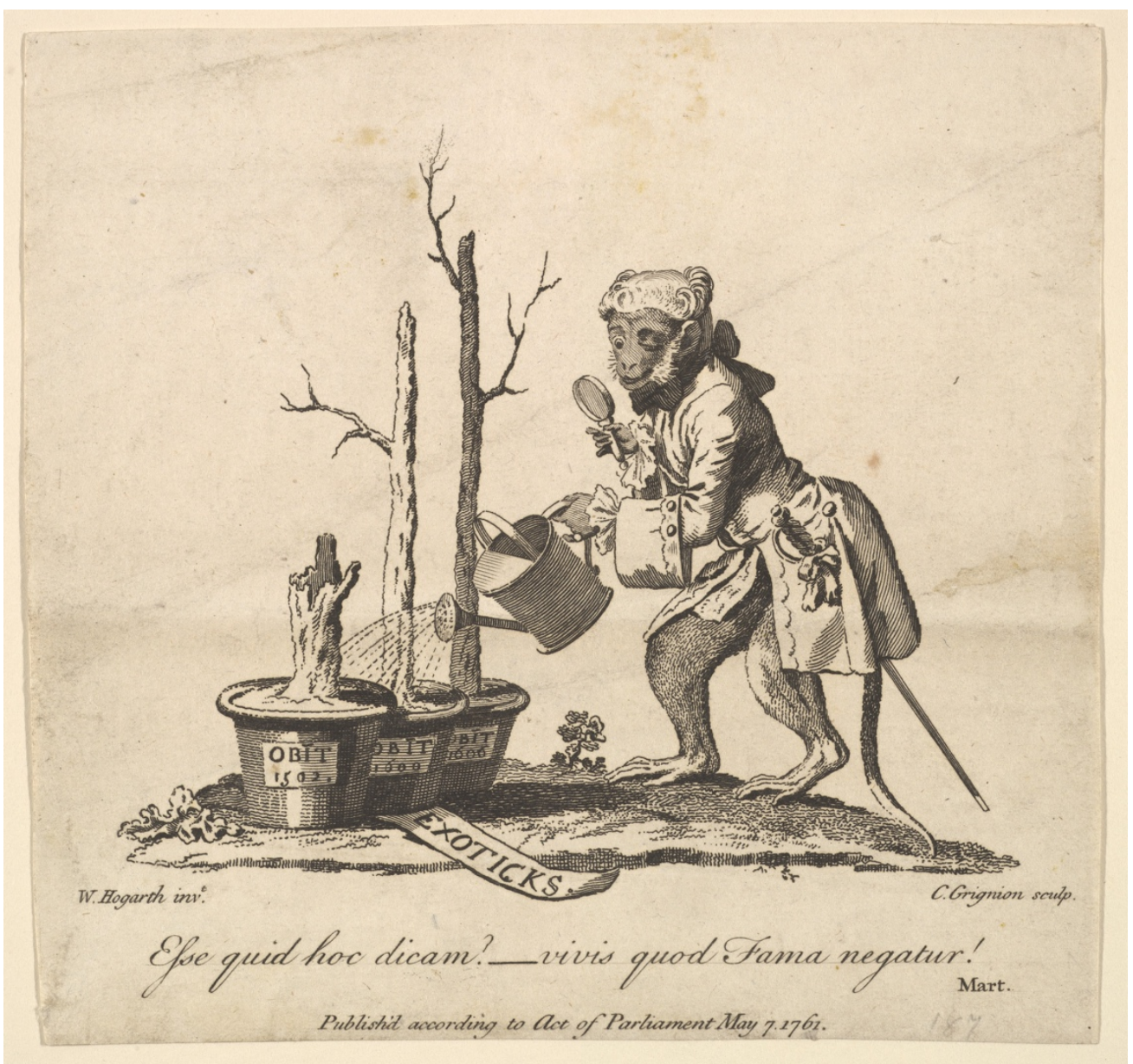

Figure 2: Tailpiece to the catalogue of pictures exhibited by the Society of Artists in 1761, drawn by William Hogarth and engraved by Charles Grignion. The Metropolitan Museum of Art, New York. Harris Brisbane Dick Fund, 1932.

Monkeys also featured in satires on medical practitioners. They frequently crop up in depictions of mountebanks - travelling medics who sold remedies by putting on an entertaining show. Those monkeys had a factual basis. Mountebanks often mounted their spectacles with the help of a clown, sometimes known as a "Merry Andrew," and a performing monkey. ${ }^{14}$ By

\footnotetext{
${ }^{14}$ M.A. Katzritsky, Women, Medicine and Theatre 1500-1750: Literary Mountebanks and Performing Quacks. (Aldershot: Ashgate, 2007), p. 81; Genice Ngg, "The Changing Face of Quack Doctors: Satirizing Mountebanks and Physicians in Seventeenth- and Eighteenth-Century England," in Stephanie M. Hilger (ed.), New Directions in Literature and Medicine Studies (Basingstoke, Hampshire: Palgrave Macmillan, 2017), 333-356, 335-36.
} 
the turn of the $18^{\text {th }}$ century, however, illustrators and printmakers generally turned the monkeys against their masters, using them to satirise the dubious sales techniques and unverifiable claims of medical expertise for which mountebanks were so frequently criticized. Consider an English print from 1690 mocking the famous Dutch mountebank Hans Buling (Figure 3):

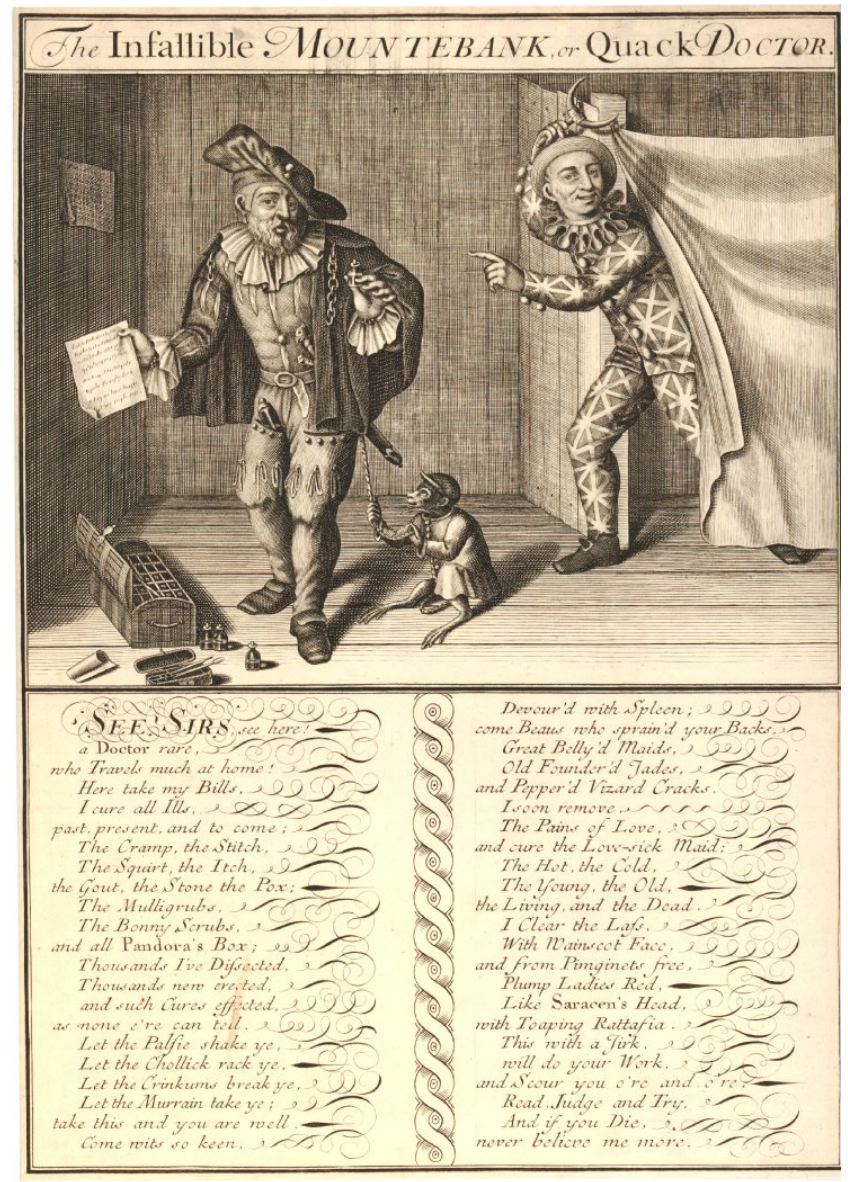

Figure 3: "The Infallible Mountebank, or Quack Doctor." Printed broadside depicting the mountebank Hans Buling, dated ca. 1688-1705. The figure of Buling comes from an image by the Dutch painter Marcellus Laroon. (C) The Trustees of the British Museum.

Here, both the Merry Andrew and the monkey seem to be having fun at Buling's expense, calling our attention to his bizarre clothing, uncouth gestures, and thus reinforcing the text's suggestion that his remedies were less effective than he claimed - or perhaps even fatal.

The ape-connoisseur and the ape-medic come together in another one of the pamphlets attacking Woodward published in 1719. Entitled A Serious Conference between Scaramouch 
and Harlequin, and perhaps written by Richard Mead, that pamphlet took its inspiration from the commedia dell'arte. Aside from a brief introduction, the text consists of a dialogue between Harlequin, who takes the side of Freind, and Scaramouch, who ineptly pleads for Woodward. Most of Scaramouch's lines come from an earlier pamphlet written in Woodward's defence by John Harris (the real Harris this time), entitled A Letter to the Fatal Triumvirate. ${ }^{15}$ As a result, the dialogue plays out as a forensic satire on Harris's arguments, mocking and refuting them one by one. The Serious Conference goes far beyond the immediate point of contention in the medical dispute - Woodward's argument that smallpox and virtually all other diseases were caused by an excess of bile in the stomach. It also deals extensively with matters of taste, including the clumsiness of Woodward's prose style, his apparent contempt for ancient learning, and his preference for collecting fossils and antiquities over paintings, drawings, and sculptures. Monkeys make three separate appearances in this wide-ranging satire. The first comes in the brief dedicatory letter written in the author's own voice. Here, the author claimed to keep a monkey at home for his amusement, asserting that the monkey's facility for imitation enabled him to soothe his anger at the "brutality" of his own species. ${ }^{16}$ The second comes in the dialogue itself, when Harlequin likens Woodward to a monkey that the household cats and dogs have mistaken for a human member of the family. Drawing on the image of the mountebank as ape, the suggestion was that Woodward had merely the external appearance of a doctor. He resembled a physician as much as an ape resembled a human. ${ }^{17}$

\footnotetext{
${ }^{15}$ Momophilius Carthusiensis [pseud.], A Serious Conference between Scaramouch and Harlequin (London, 1719). The English Short Title Catalogue identifies Mead as the author, a supposition perhaps borne out by the pamphlet's defence of collecting paintings - one of Mead's key interests. On the pamphlet's use of the commedia dell'arte, see Craig Ashley Hanson, "Dr Richard Mead and Watteau's 'Comédiens Italiens'," The Burlington Magazine 145:1201 (2003), 265-272, pp. 266-270. The earlier pamphlet by Harris had been published anonymously as A letter to the fatal triumvirate: In answer to that pretended to be written by Dr. Byfield (London, 1719).

${ }^{16}$ Serious Conference, p. ii (note 15).

${ }^{17}$ Ibid., p. 6.
} 
The monkey's third appearance, however, is subtler. It comes about a third of the way through, when Harlequin attacks Harris-Scaramouch's suggestion that Mead's involvement with the fine arts amounted to knowing only "how to buy gawdy Prints or Drawings." Far from damaging Mead's credibility with this remark, however, Harelquin asserted that HarrisScaramouch had simply revealed his own poor taste:

why should'st thou take so much Pains to expose thy Ignorance in Pictures? We were very well satisfied before (by thy choice of a Client) of thy Taste; and that a Dutch Piece of a Mountebank, with all his Grimaces, and Apish Gestures, wou'd give thee more pleasure than the best Antique Bust of an Hippocrates or a Galen; or a Kneller's Portrait of a Radcliffe, a Mead, or a Freind. ${ }^{18}$

This densely layered joke begins by suggesting that Harris-Scaramouch had made his poor taste known long before he attacked Mead's connoisseurship. Simply by associating himself with Woodward, the joke implies, Harris had made it clear that he liked mountebanks more than real doctors. It was thus clear that he would enjoy the uncouth image of a Mountebank made by a Dutch artist rather than the truly beautiful depictions of medical practitioners exemplified by ancient busts of Hippocrates and Galen, or Godfrey Kneller's (1643-1723) more recent portraits of Radcliffe, Mead and Freind. ${ }^{19}$ Referring to the "Apish gestures" of the mountebank, moreover, the joke hints that Woodward himself had ape-like qualities. The Serious Conference

\footnotetext{
${ }^{18}$ Ibid., p. 10.

${ }^{19}$ On classical portrait busts and Mead's self-fashioning, see Jordanova, "Portraits, People and Things," 297-301 (note 5). Such busts appear in portraits of Mead and Freind. Only John Radcliffe (1650-1714) actually sat for Kneller, resulting in a portrait now at the Bodleian Library, Oxford.
} 
therefore hints that Woodward's failures in medicine and connoisseurship were caused by the animality of his mind and body.

\section{The mind and the animal machine}

Taken on its own, the Serious Conference pamphlet does not furnish conclusive proof that Mead and his supporters identified something animalistic about their opponent. After all, the ape was a stock trope of early modern satire, frequently used to mock those considered either pretentious or self-important. By the turn of the $18^{\text {th }}$ century, however, the ape had acquired new significance in the context of medical and natural-philosophical debates about the boundaries between human and animal life. Edward Tyson's (1651-1708) Orang-Outang, sive Homo Sylvestris: or, the Anatomy of a Pygmie Compared with that of a Monkey, an Ape, and a Man, for instance, had a considerable impact on many of those who read it. As well as being recirculated in abridged form, Tyson's demonstration of the striking similarities between human and chimpanzee anatomy figured prominently in works of literature and satire. Indeed, as Laura Brown has shown, it was a crucial source for Jonathan Swift's powerful reflections on the difficulty of distinguishing between humans and animals in the fourth part of Gulliver's Travels. ${ }^{20}$ In the pamphlet announcing Woodward's death - the Sickness and Death - there is an obvious echo of this preoccupation with the role that comparative anatomy might play in distinguishing humans from animals. As we saw at the outset, the pamphlet uses the animality of Woodward's internal organs - including his simian testicles - to signal that his outward resemblance to other humans concealed an inner animal physiology. Referring in its footnotes to real works of comparative anatomy by the Dutch physician Gerard Blasius (1627-1682) and

\footnotetext{
${ }^{20}$ Laura Brown, Homeless Dogs and Melancholy Apes: Humans and Other Animals in the Modern Literary Imagination (Ithaca and London: Cornell University Press, 2010), pp. 46-53; G.S. Rousseau, "Madame Chimpanzee," in G.S. Rousseau, Enlightenment Crossings: Pre- and Post-Modern Discourses Anthropological (Manchester: Manchester University Press, 1991), pp. 198-209.
} 
the English physician Thomas Willis (1621-1675), the pamphlet thus explicitly signals its indebtedness to contemporary scientific debates about the differences and similarities between humans and animals. ${ }^{21}$

To understand what Woodward's antagonists meant when they portrayed him as a brute beast, and the significance of that portrayal for their objections to both his medicine and his connoisseurship, we must therefore consider contemporary ideas about the role of anatomy in distinguishing between humans and animals. Most thinkers of the early $18^{\text {th }}$ century regarded the immaterial soul or intellect as the crucial point of difference between humans and animals. According to conventional wisdom, it was the possession of such a soul that made the human mind superior to that of animals, giving humans an apparently unique capacity for cognitive operations such as abstract reasoning or the acquisition and use of language. If the immaterial soul distinguished humans from animals, the body was the thing they had in common. Humans stood at the central point in the scale of nature, connected to God through the possession of an immaterial soul, and to material things, including animals, through the possession of a body. ${ }^{22}$

In England, it was the physician and anatomist Thomas Willis who played the leading role in using comparative anatomy to search out the precise boundary between the mental operations carried out by the material agency of the body, and those brought about instead by the immaterial agency of the soul. He published his comparative anatomy of the brain and nerves, Cerebri Anatome, cui accessit Nervorum Descriptio et Usus in 1664, and his thoughts

\footnotetext{
${ }^{21}$ Sickness and Death, pp. 9-12 (note 1). The anatomical works cited are Thomas Willis, Cerebri Anatome: cui accessit Nervorum Descriptio et Usus (London, 1664), and Miscellanea Anatomica, Hominis, Brutorumque Variorum, Fabricam Diversam Magna Parte Exhibentia (Amsterdam, 1673).

${ }^{22}$ See Anita Guerrini, Experimenting with Humans and Animals: From Galen to Animal Rights (Baltimore: Johns Hopkins University Press, 2003), p. 22. Robert Wokler and Peter Harrison have shown that the move towards mechanical models of explanation in the $17^{\text {th }}$ century boosted the notion that the possession of an immortal, immaterial soul distinguished humans from animals. Insisting on the passivity of matter, philosophers such as René Descartes saw animals as highly complex machines, lacking spiritual agency of their own. See Peter Harrison, "The Virtues of Animals in Seventeenth-Century Thought," Journal of the History of Ideas 59:3 (1998), 463-484, 480-81, and Robert Wokler, "From l'homme physique to l'homme moral and back: towards a history of Enlightenment anthropology," History of the Human Science 6:1 (1993), 121-138, 122-23.
} 
on the physiology and pathology of the mind as De Anima Brutorum in 1672. For Willis, the physical resemblance between human and animal brains was a compelling argument for the existence and activity of the immaterial, immortal soul. Since there was virtually no material difference between the brains of humans and those of larger mammals, he reasoned, the only way to explain the differences in their cognitive abilities was by assuming the presence of an immaterial principle that existed outside the world of observable phenomena. At the same time, Willis argued that the physiological similarity between the brains, nerves, and sensory organs of humans and animals explained why they had so many affective states and cognitive abilities in common, extending as far as the expression of desire and the ability to learn simple tasks. It was for this reason that Willis's De Anima Brutorum, ostensibly a treatise on the soul of brute animals, dealt extensively with the affective and cognitive world of humans. For Willis, the "soul of brutes" was a material entity possessed by humans and animals alike, its operations explicable in the mechanical terms of fluids passing through passages in the body. ${ }^{23}$

Reinforcing conventional wisdom with the authority of comparative anatomy, Willis identified a sharp distinction between the mental operations carried out by the immaterial soul, and those dependent on the body. In practice, however, he did not stick to this dualist position, instead engaging in just the kind of reductive materialism parodied in the Sickness and Death. Consider, for instance, his treatment of the additional set of nerves between the heart and brain, apparently possessed by humans alone. As William F. Bynum has noted, Willis insisted that this nervous pathway was somehow a physiological manifestation of the cognitive advantages enjoyed by humans over animals. Willis backed up this claim, moreover, by asserting that he

\footnotetext{
${ }^{23}$ Thomas Willis, De Anima Brutorum (Oxford, 1672), p. 124. For an English version, see Thomas Willis, "Two Discourses Concerning the Soul of Brutes," in Thomas Willis Dr. Willis's Practice of Physick, Being the whole Works of that Renowned and Famous Physician, trans. Samuel Pordage (London, 1684), p. 44. The "Two Discourses" have their own pagination. See also Alexander Wragge-Morley, "Imagining the Soul: Thomas Willis (1621-1675) on the Anatomy of the Brain and Nerves," in Chiara Ambrosio and William Maclehose (eds.) Imagining the Brain: Episodes in the History of Brain Research, Progress in Brain Research (Academic Press/Elsevier, 2018), pp. 55-73, 60-61.
} 
had found this pathway to be far smaller than usual when dissecting a human who had grown to adulthood without developing the capacity for rational thought. The implication, in other words, was that the deficiency in this pathway had made the person he dissected into an irrational animal, unable to exercise the higher cognitive faculties associated with the immaterial soul. Making this suggestion, however, Willis abandoned the premise upon which his project otherwise depended - that the intellect was immaterial, and that its operations did not depend upon the bodily structures of the brain and nerves. ${ }^{24}$

Despite such difficulties, as G.S. Rousseau has shown, Willis's argument had a considerable influence on British ideas about the physiology of the mind during the late $17^{\text {th }}$ and early $18^{\text {th }}$ centuries. $^{25}$ Very few thinkers agreed with the exact details of Willis's imaginative hypothesis about the workings of the brain and nervous system. Yet virtually all of them pursued a similarly ambiguous approach to the boundaries between matter and spirit, associating bodily structures with the operations of the intellect despite believing - or claiming to believe - that the intellect lay beyond the realm of material causation. ${ }^{26}$ The London-based physician James Parsons (1705-1777), for example, came up against this contradiction in his Croonian lectures on muscular motion, addressed to the Royal Society in 1745 and 1747. In the first of those lectures, he asserted that the soul was distributed throughout the whole body, bringing about voluntary action by transmitting motion to whichever part of the body it desired to move. In the second lecture, however, he argued that the diaphragm was responsible for transmitting the demands of the will to the body. He thus reversed his initial position, implying

\footnotetext{
${ }^{24}$ William F. Bynum, "The Anatomical Method, Natural Theology, and the Functions of the Brain," Isis 64:4 (1973), 444-468, 457. Cf. Willis, Cerebri Anatome (London, 1664), pp. 356-57. For an English version, see Thomas Willis, "The Anatomy of the Brain," in Thomas Willis Dr. Willis's Practice of Physick, Being the whole Works of that Renowned and Famous Physician, trans. Samuel Pordage (London, 1684), p. 132. The "Anatomy of the Brain" has its own pagination.

${ }^{25}$ G.S. Rousseau, "Nerves, Spirits and Fibres: Toward the Origins of Sensibility (1975)," in G.S. Rousseau, Nervous Acts: Essays on Literature, Culture and Sensibility (Houndmills: Palgrave Macmillan, 2004), pp. 157184, 165-174.

${ }^{26}$ Wragge-Morley, “Imagining the Brain,” pp. 69-70 (note 23).
} 
that the soul needed a material structure through which to communicate its will. Neither Parsons nor Willis succeeded in resolving the tension between their desire to work out the animal mechanisms of sensation and cognition, and their belief that the highest operations of the mind could only be explained by the immaterial agency of the rational soul. ${ }^{27}$

\section{Woodward, Mead, and the materiality of the mind}

Through its description of Woodward's internal organs, the Sickness and Death pamphlet thus made direct reference to what, by the early $18^{\text {th }}$ century, was a widespread interest in identifying the bodily causes of mental dysfunction. The point, however, was not simply to depict Woodward as a man with an animal mind. At the same time, the author sought to discredit one of Woodward's key medical theories. In the State of Physick, Woodward had asserted that the stomach played a decisive role in the life of the mind, with the bilious salts arising from the digestion of food leading to the formation of thoughts in the brain. What Woodward had in effect done, therefore, was to argue that the mind was in some sense controlled by the animal body rather than the immaterial soul. Rather than attributing the formation of thoughts to the activity of the immaterial soul, he assigned it to the material agency of the stomach digesting food - a process common to humans and animals alike. ${ }^{28}$

Perhaps drawing on the mock anatomies published some seven years earlier by the critic and aesthetic theorist Joseph Addison (1672-1719), the author of the Sickness and Death mocked Woodward's hypothesis by stretching out its logic to the point of implausibility. The

\footnotetext{
${ }^{27}$ James Parsons, "The Crounian lectures on muscular motion. For the years MDCCXLIV and MDCCXLV," Philosophical Transactions of the Royal Society 43:477 (1745), 51-52. Cf. James Parsons "Human Physiognomy Explain'd: in the Crounian Lectures on Muscular Motion. For the Year MDCCXLVI," Philosophical Transactions of the Royal Society 44:479 (1747), 34.

${ }^{28}$ John Woodward, The State of Physick: and of Diseases; with an Inquiry into the Causes of the late Increase of them: But more particularly of the Small-Pox (London, 1718), pp. 6-7, 14-16.
} 
pamphlet thus fantasizes a scenario in which the effects of the bilious salts on Woodward's cognitive faculties were visible to the gaze of the anatomist in the shape and texture of the brain. The joke refers indirectly, moreover, to the difficulty of reconciling such a hypothesis to the commonplace belief that the mind's highest operations depended not on the mechanisms of the body, but rather on the activity of the immaterial soul. As we have seen, the Sickness and Death concludes with the remark that Woodward's pineal gland was "perfectly flaccid," making it impossible for the soul supposedly resident there to transmit its commands to the will. Mobilising Descartes's already discredited - but nevertheless widely discussed - suggestion that the pineal gland was the seat of the soul, the Sickness and Death invites us to question the notion that a bodily organ could interfere with the operations of an immaterial entity. The pamphlet thus reproduces - albeit for comedic effect - the same ambiguous dualism identifiable in Willis's comparative anatomies. On the one hand, the pamphlet uses the deformed state of Woodward's internal organs to explain his alleged failures as both a medic and a connoisseur. On the other hand, however, it uses the impossibility of explaining the interactions between matter and spirit to cast doubt not only on Woodward's argument for the stomach's influence over the mind, but on any attempt to explain the workings of the immaterial intellect in material terms. $^{29}$

I do not think, however, that the Sickness and Death's rejection of Woodward's hypothesis concerning the stomach's interactions with the mind - nor even its recognition of the difficulty of figuring out how the soul interacted with the animal body - betokened a rejection of the more general suggestion that he had made in the State of Physick. That is, the

\footnotetext{
${ }^{29}$ Sickness and Death, pp. 9, 12 (note 1). Both Joseph Addison and the philosopher George Berkeley (16851753) satirised Descartes's suggestion that the soul inhabited the pineal gland. See Roger D. Lund, "Martinus Scriblerus and the Search for the Soul," Papers on Language and Literature 25:2 (1989), 135-150, 143-146. In his Cerebri Anatome (1664), Thomas Willis rejected Descartes's hypothesis about the pineal gland. See Claire Crignon, "Chapter 10: How Animals may help us Understand Men," in Stefanie Bucheneau and Roberto Lo Presti (eds.), Human and Animal Cognition in Early Modern Philosophy and Medicine (Pittsburgh: University of Pittsburgh Press, 2017), pp. 173-185, 176.
} 
suggestion that the animal body, especially when put into a state of disorder, could decisively influence the operations of the mind. It is true that Woodward's critics vehemently objected to his proposal that the bilious salts produced by the stomach furnished the mind with the materials it needed for thought. However, the materialism latent in the work of dualist medics and philosophers should caution us against taking the Sickness and Death's satire on Woodward's hypothesis at face value. In their own writings, Woodward's antagonists put forward strikingly similar hypotheses when seeking to explain how sicknesses of the body could prejudice the operations of the supposedly immaterial intellect. Insinuating that Woodward was more ape than man, they satirically exploited a worry that both he and they raised when discussing the pathology of the mind - that physical disorders might render the intellect incapable of imposing its will on the body, in effect making the human into a brute beast.

As suggested by his likely authorship of the Serious Conference, Richard Mead was one of Woodward's most committed antagonists. If we closely compared Woodward's position with one that Mead had articulated some years earlier, however, we can find a good deal of shared ground. ${ }^{30}$ Unlike the majority of his contemporaries, Woodward offered an almost entirely materialist account of the mind, framed in the mechanical terms of hydrostatics and chemistry. Let's return to the State of Physick, considering again Woodward's assertion that the bilious salts influenced the mind:

As these Salts are the Instruments that concur to the Produceing of Cogitation [...]. Being depraved, they confound and pervert the Power of Thinking: bring

\footnotetext{
${ }^{30}$ This impression is confirmed by the fact that the pamphlet war culminated in a sword fight between Mead and Woodward. See Levine, Dr. Woodward's Shield, pp. 16-17 (note 4).
} 
on Solicitude, Anxiety, Suspicion. Nay they obtrude suppositititous [sic.]

Thoughts, and Suggestions [...] directly contrary to the Will of the Person.

Here, Woodward gave the animal machine complete command over the mind, making only an oblique reference to the immaterial soul when he asserted that "the Will" could do nothing to prevent the bilious salts from provoking unwanted ideas and affective states. At no other point in the text did he mention the immaterial soul by name, let alone try to explain how it could be affected by the passage of saline fluids from the stomach to the brain. Perhaps unwilling to enter the speculative terrain of debates about the interactions between the soul and body, Woodward offered a mechanical account of the mind and its pathologies. ${ }^{31}$

Mead gave the immaterial soul a far more important role in his own discussions of the pathology and therapeutics of the mind. Yet the disagreement between the two medics was less significant than it seems. Consider a section from the Mechanical Account of Poisons (1702), where Mead tried to integrate the soul into a mechanical explanation for the state of delirium caused by tarantula venom. Mead's difficulty was that he regarded the immaterial soul as the sole cause of the voluntary motion. But he also wanted to show that mechanical agents - in this case the chemical changes wrought by a poison - could stir up the bodily motions experienced by delirious patients. Mead's solution was to assert that the immaterial soul formed habits. When the mind was working normally, he argued, the soul learned to respond to the most common forms of sensory experience by habit rather than deliberation, unconsciously willing the body into motion whenever it experienced them. When, however, a poison or another agent disordered the the brain and nervous system so much that they presented the mind with images that were either false or out of order, the soul would not be immediately capable of setting aside

\footnotetext{
${ }^{31}$ Woodward, State of Physick, p. 16 (note 28).
} 
its customary routine. Instead, it would respond to those irregular images as if they were normal, propelling the body into a concomitantly irregular series of motions. ${ }^{32}$

For Mead, the advantage of this unlikely supposition was that it enabled him to incorporate the immaterial soul into his explanation for delirium without making it responsible for the unpleasant, irrational motions caused by that malady. The soul was not to be faulted when a bodily disorder, brought about by mechanical causes, curtailed its rational decisionmaking agency:

For, as in the former State of Things a Man is said to act Rationally, so this latter Case is call'd a Perturbation of Mind, that is, a Delirium; tho' it is very manifest, that in reality the Defect is not in the Rational, but Corporeal Part; such Species being really presented to the Mind, upon which by the Order of our Constitution such Motions ought to follow in the Body.

Mead's argument resolved into much the same point that Woodward made some sixteen years later. Disturbances of the mind took place when bodily disorders led the organs of sensation and cognition to displace the supposedly rational will from its command over the immaterial soul. Despite making contrasting suggestions about the presence and activity of the soul, the two medics agreed on this fundamental point. Disorders of the brain and nervous system had the potential to make humans into animal machines, guided not by the putatively rational determinations of the soul, but instead by the disturbed impulses of the pathological body. ${ }^{33}$

\footnotetext{
${ }^{32}$ Richard Mead, A Mechanical Account of Poisons in Several Essay (London, 1702) p. 66.

${ }^{33}$ Mead, Mechanical Account, pp. 66-67 (note 32). For an acute discussion of this problem in the thought of Mead and his contemporaries, see Akihito Suzuki, "Dualism and the Transformation of Psychiatric Language in the Seventeenth and Eighteenth Centuries," History of Science 33:4 (1995), 417-447, 422-432.
} 


\section{Medicine, aesthetic experience, and the pathological body}

Woodward and his enemies vehemently disagreed about the causes and cures of disease, and with as much bitterness about matters of taste and connoisseurship. As we have just seen, however, they agreed that the mind could easily be prevented from exercising its proper functions when the mechanisms of the animal body were thrown into a state of disorder. When Freind and his allies claimed that Woodward had the body of a monkey, they were clearly exaggerating. However, their joke depended on an argument that commanded wide assent among medics and natural philosophers, including Woodward himself. The joke assumed that the animal body - especially in pathological states - was the cause of the intellectual and moral deficiencies that might lead an individual to make bad judgments, whether about causes and cures of disease, or about the value of curiosities and works of art. Despite disagreements about the agency and activity of the immaterial soul, medics on both sides of the dispute tended to agree that disorders of the mind had material causes, and that the way to address those causes was through the material agency of medical treatments.

This unacknowledged materialism found its way into theories of aesthetics and connoisseurship through the burgeoning field of medical practice and theory concerned with the psychosomatic condition known as melancholy. By the early $18^{\text {th }}$ century, the wider public increasingly referred to that condition as the spleen, while physicians generally referred to it either as hypochondria if the sufferer was male, or hysteria if the sufferer was female. ${ }^{34}$ As all four names suggest, the condition was understood to be a mental disturbance arising when some disorder in the lower body, whether the genitals, liver, stomach, spleen, or womb, had unduly influenced the mind. Hypochondria was thus latent in the debate between Woodward and his

\footnotetext{
${ }^{34}$ In the second half of the $17^{\text {th }}$ century, physicians generally argued that hypochondria and hysteria were the same disease, rejecting the earlier diagnosis of hysteria as a condition associated specifically with the womb. See Sabine Arnaud, On Hysteria: The Invention of a Medical Category between 1670 \& 1820 (Chicago: University of Chicago Press, 2015), pp. 17-18. Cf. Thomas Sydenham, Processus Integri in Morbis fere Omnibus Curandis (London, 1692), p. 5, "De affectione, in fœminis, hysterica; maribus, hypochondriacá dictá."
} 
antagonists, who both used the standard symptoms of that condition in their own descriptions of mental illness. ${ }^{35}$

With the exception of outright materialists such as Mandeville, physicians specialising in hypochondria generally held that the mind depended on an immaterial soul. In practice, however, they tended to ignore the soul, focusing instead on material causes and therapies. In so doing, they preserved the traditional emphasis on the lower body, arguing that the process of filtering nutrition out of the stomach and into the circulatory, lymphatic, and nervous systems had a decisive role in causing the condition. Like Freind and Mead, therefore, they almost invariably depicted mental illness, stupidity, and bad judgment as pathologies of the animal body. In his $A$ Treatise of the Spleen and Vapours (1725), for instance, the physician and poet Richard Blackmore (1654-1729) remarked insightfully on the difficulties involved with reconciling his bodily explanations for differences in mental capacity with his belief in the existence and agency of the immaterial soul. One the one hand, the embodied model of cognition would make "a great and admirable Genius $[\ldots]$ result from some curious Structure of the Brain, from regular and exalted Ferments, and more immediately from the Fineness, Vivacity, and abundance of the Spirits [...]." On the other hand, he pointed out that such an elevated mind might simply be explained by the possession of a better immaterial soul, unaffected by whatever happened to be going on in the body. For the most part, however, Blackmore simply ignored this dilemma, and its consequences for his own belief in the immateriality of the soul. In the pages following this discussion, he exhaustively described the bodily causes of stupidity and poor judgment. Moreover, Blackmore explicitly linked hypochondria to poor aesthetic judgment, describing the precise form of hypochondria apt to turn people into bad judges of poetry. "If Hypocondriacal Fury has the Superiority in the

\footnotetext{
${ }^{35}$ Compare their descriptions of mental disorder with Sydenham, Processus Integri, p. 5 (note 34), "sanitatis recuperandæ spes omnis protinus abjicitur, \& tristissima quævis sibi ominantur ægrota [...].”
} 
[humoral] Mixture," he wrote, "a Progeny is produced of shining Fops, Poetasters, petulant Laughers, or morose false Criticks."

As I have shown elsewhere, the the two key aesthetic theorists of the 1700 s and 1710 s - Joseph Addison and the philosopher Anthony Ashley Cooper, third Earl of Shaftesbury (1671-1713) - also turned to hypochondria in their efforts to define the ideal forms of experience they hoped to obtain through the cultivation of good taste in the arts and literature. ${ }^{37}$ In his Characteristicks of Men, Manners, Opinions, Times (1711), Shaftesbury portrayed the experience of beauty as a supremely rational form of pleasure - a state of spiritual inspiration arising from the realisation that genuine beauty was an expression of the wisdom, goodness, and power of God. He worried, however, that it might be hard to distinguish this genuine state of inspiration, accompanied by a licit form of spiritual pleasure, from the false or superstitious forms of inspiration to which many people then laid claim. To address this problem, Shaftesbury drew on the vocabulary of hypochondria. ${ }^{38}$ From the second half of the $17^{\text {th }}$ century onwards, medics and natural philosophers increasingly diagnosed supposedly superstitious expressions of religiosity as manifestations of that condition. Using the pejorative label of enthusiasm, they asserted that neither visions of angels and demons, nor prophetic inspiration, were genuine spiritual experiences. Instead, physicians characterised them as illusory visions prompted by some disorder in the lower body. For Shaftesbury, too, the religious form of hypochondria was the embodied, animal counterpart to that inspired state. Following conventional medical

\footnotetext{
${ }^{36}$ Richard Blackmore, A Treatise of the Spleen and Vapours: or, Hypocondriacal and Hysterical Affections (London, 1725), especially p. 238 and p. 257 on the immaterial soul, and pp. 257-284 on bodily causes of intellectual and moral dispositions.

${ }^{37}$ Alexander Wragge-Morley, Aesthetic Science: Representing Nature in the Royal Society of London, 16501720 (Chicago: University of Chicago Press, 2020), pp. 168-171.

${ }^{38}$ Anthony Ashley Cooper, Third Earl of Shaftesbury, "Miscellaneous Reflections on the Preceding Treatises and Other Critical Subjects," in Shaftesbury, Characteristics of Men, Manners, Opinions, Times, ed. Lawrence E. Klein (Cambridge: Cambridge University Press, 2000), p. 355. See also Michael Heyd, "Be Sober and Reasonable": The Critique of Enthusiasm in the Seventeenth and Early Eighteenth Centuries (Leiden: Brill, 1995), pp. 224-25.
} 
wisdom, he insinuated that enthusiasm arose not from the rational determinations of the immaterial soul, but instead from the irrational impulses and pathologies of the lower body. ${ }^{39}$

Addison used a different strategy to distance the pleasures of aesthetic experience from those of the lower body. In his famous essays "On the Pleasures of the Imagination" (1712), Addison argued that aesthetic pleasure arose not from the lower body, but rather from the activity of the imagination - a mental faculty of ambiguous ontological status that somehow mediated between the immaterial soul and the mechanisms of the body. He thus aligned aesthetic pleasure less closely with the operations of the immaterial soul than Shaftesbury. Nevertheless, he used the vocabulary of hypochondria when explaining why the imagination sometimes succumbed to unwanted visions that fell short of his ideal. When the mind is “disordered by Dreams or Sickness," he explained, "the Fancy [imagination] is over-run with wild dismal Ideas, and terrified with a thousand hideous Monsters of its own framing." ${ }^{40}$ For both Shaftesbury and Addison, hypochondria was a model against which to define the refined models of aesthetic experience they sought to associate with the cultivation of good taste. Making much the same argument as the medics specializing in hypochondria, they portrayed unpleasant or inappropriate states of mind as pathological symptoms, occurring when the lower body had somehow gained the upper hand over the higher faculties.

Focusing on the pathologies and therapies of the animal body, therefore, we can understand why medics such as Mead and Woodward so closely connected their disagreements about connoisseurship and aesthetic judgment to their disputes about the causes and cures of disease. What the two domains had in common was a concern about the interactions between the soul and body. Although they acknowledged the power of the organs of the body over the

\footnotetext{
${ }^{39}$ Heyd, Critique of Enthusiasm, pp. 191-96 (note 38).

${ }^{40}$ Joseph Addison, The Spectator, ed. Donald F. Bond, 5 vols. (Oxford: Oxford University Press, 1987), vol. 3, no. 421 , p. 579 .
} 
exercise of judgment, they nevertheless worried that an excessively embodied mind would be, in effect, the mind of an animal. In addition, I have suggested that key figures in the early history of British aesthetic theory - such as Shaftesbury and Addison - shared this embodied account of the mind, expressing similar concerns about how the body might turn refined judgments about beauty into pathological expressions of the animal appetites. We may therefore wish to reconsider the place of mind-body dualism in the intertwined histories of European medicine, aesthetics, and connoisseurship in the early $18^{\text {th }}$ century. I do not mean to suggest that the distinction between soul and body had no meaning at the time, or that it has no heuristic value for scholars today. In debates about both the causes and cures of disease, and about the consumption of rare and precious things, that distinction had an important role. It would be mistaken, however, to assume that those who insisted on the immateriality of the soul actually saw the mind as a disembodied entity. Despite paying lip service to the immateriality of the soul, the art theorists, connoisseurs, and medics of Woodward's generation devoted intense attention to the mechanisms and pathological states that threatened the rational soul's from command over the body. Seeking not to become animals, they nevertheless revealed the immense power of the animal body over the most refined operations of the mind. 